\title{
Earnings Management: The Role Of Accounting Professionals
}

\author{
Paul J. Carruth, (E-mail: pcarruth@selu.edu), Southeastern Louisiana University
}

\begin{abstract}
In today's financial markets there is a great deal of pressure for corporations to meet investors' earnings expectations. Failure to do so may result in the loss of millions of dollars in stock capitalization. As a result, an increasing number of corporate executives have succumbed to the temptation to "manage" their earnings in order to achieve targeted profits. The number of companies under investigation by the Securities and Exchange Commission (SEC) for possible accounting fraud related to earnings management has increased significantly in recent years. This article identifies and discusses four common areas of potential financial reporting abuse: restructuring costs, miscellaneous reserve accounts, materiality, and manipulation of revenue recognition. In addition, this paper discusses the vital role of accounting professionals as gatekeepers responsible for helping to maintain the viability of our financial markets.
\end{abstract}

\section{Introduction to the Problem}

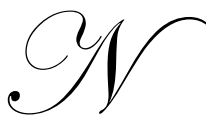

et income and earnings per share information reported by companies represents some of the most important data available to investors. This bottom line information is particularly significant to many readers of financial statements because it has a sense of finality and a ring of truth. The importance of this statistical information can be witnessed by the fact that a reported earnings per share figure that is a few pennies below analysts expectations can result in a dramatic decline in the share price of a company's stock. For start up companies seeking new capitalization or for established mainline companies, the implications of a 5\%, $10 \%$, or even larger drop in stock prices are formidable.

As the result of this pressure, corporate executives may at times feel inclined to manipulate their company's earnings. Earnings manipulation has been defined as a situation in which a company's management violates generally accepted accounting principles (GAAP) in order to favorably represent the company's financial performance (Beneish, 1999). Because investors tend to prefer companies that demonstrate steady growth, some corporate managers feel compelled to manipulate earnings in order to show steady, continuous, upward growth in their profits.

The role of financial reporting is to provide and communicate information that assists in business decisionmaking. Timely, sufficiently detailed, and high quality information is essential for investors to make sound investment decisions. However, according to the Securities and Exchange Commission (SEC), misleading financial reports are being issued at a startling rate (Schroeder, 2001). This is evidenced by the fact that a study by the Financial Executives International group reported that the number of financial restatements issued in the last three years was higher than the previous ten years combined (Weil, 2001). The increased pressure on corporate executives to meet investors' expectations has driven many of them to not only bend the accounting rules to the breaking point, but also in some cases to deliberately manipulate reported earnings. Under increased scrutiny from the SEC regarding the issue of "managed earnings", these companies have found it necessary to restate previously misleading financial statements. The purpose of this paper is to identify examples of common abuses associated with the deliberate attempt by corporate management to manipulate their earnings report. In addition, the role that accounting professionals, as well as the Securities and Exchange Commission, play in preserving the integrity and

Readers with comments or questions are encouraged to contact the author via e-mail. viability of the capital markets in the United States will be examined. 


\section{Earnings Management}

In 1998, then Chairman of the SEC Arthur Levitt expressed increasing concern that the desire by corporations to meet investors earnings expectations was resulting in an erosion in the quality of financial reporting (Levitt, 1998). He expressed concern that the motivation to achieve consensus earnings estimates prompted many corporate managers to engage in earnings manipulation in order to project a pattern of smooth corporate earnings. Mr. Levitt expressed frustration on the part of the SEC regarding areas where integrity in financial reporting was losing out to illusion, where gray areas in accounting were being abused for corporate gain, and where corporate earnings reports reflect the hopes of management rather than the underlying performance of the company. There are a number of approaches corporations have engaged in to manipulate their reported earnings. The following discussion focuses on four common areas of abuse: restructuring costs, miscellaneous reserves, materiality, and manipulation of revenue recognition.

\section{Restructuring Costs}

Companies regularly assess the efficiency and profitability of their business segments in order to remain competitive. This assessment may result in a decision to restructure the organization. Expenses associated with restructuring are segregated from other expenses on the income statement in order to isolate the impact of nonrecurring items on the net income. This segregation helps readers of the statements better understand the earnings associated with the normal, recurring activities of the business. However, it has become increasingly common for companies to use what is referred to as the "big bath" strategy with their restructuring charges. The approach used is to combine a large amount of costs that should be properly written off over a number of years and then expense them all in one quarter of restructuring. This is often done in a down quarter that is already fated to disappoint investors. The idea is to take a one time big hit to earnings, clean up mistakes of the past, and get the bad news behind the company. Why would a company what to exaggerate these charges? The argument is that investors are willing to look beyond a one time loss and focus on future prospects. Presumably, the large write-offs then clear the way for the company to meet or exceed future earnings expectations. In addition, if the charges are over estimated and fail to fully materialize, they provide a cushion for the future. For example, in $1997 \mathrm{Heinz}$ overestimated the cost of its restructuring by about $\$ 25$ million. When it later restated that amount, it did so by directly enhancing the operating income of a subsequent year (Sherman and Young, 2001). This financial reporting is misleading to investors, and the SEC has been openly critical of such financial reporting.

\section{Miscellaneous Reserves}

Corporate executives keep a constant eye on the market price of their companies stock. They know that investors do not like unpleasant earnings surprises, so they are motivated to try to keep net income moving at a steady upward trend. One approach used by some companies is to establish a miscellaneous or special reserve account in which unrealistic estimates are used to establish liabilities for such items as bad debts, losses from loans, future warranty costs, and sales returns. During prosperous periods, companies can exaggerate the expenses associated with these items, thus avoiding the difficulty of matching such a high level of net income in succeeding periods. At the same time, excessive reserves are built up that can be drawn upon to offset losses in down years. Thus, executives are able to achieve a smooth upward net income trend by "managing their earnings."

Xerox Corporation is an example of a major company that found itself caught up in the questionable practice of managing earnings. Xerox recently restated its earnings for the years 1998, 1999, and 2000, and acknowledged that it had misapplied some generally accepted accounting principles (GAAP) in a number of ways, including the improper use of a $\$ 100$ million reserve used to offset unrelated expenses (Schroeder, 2001). This apparent abuse of financial reporting attracted the attention of the SEC, which is conducting a broad inquiry into its accounting practices.

In another example, the SEC settled civil fraud charges with four executives of Paracelsus Healthcare Corporation. The SEC alleged that they caused the company to substantially overstate its reported earnings by $9 \%$ to 
$303 \%$ during the period from 1993 to 1996 . The four executives agreed to pay fines totaling $\$ 250,000$ in settlement of SEC charges that they, among other things, created a $\$ 16$ million reserve that was used to conceal a decline in earnings (Kirchheimer, 2001). In response to the settlement, the SEC stated that when companies issue misleading financial reports, the public faith in the financial markets is undermined.

\section{Materiality}

The principle of materiality underscores the concept that some financial transactions are so insignificant that they are not worth measuring and reporting with exact precision. For example, some companies may define an item as material only if it affects earnings by more than $5 \%$ to $10 \%$. This principle allows for some judgement and flexibility in financial reporting. However, this principle can be misused by companies that seek to do so. For instance, a company could deliberately manipulate revenues or expenses, and yet do so within an established maximum percentage of acceptability and claim the misstatement is not material.

In 1999 W.R. Grace \& Company settled an earnings manipulation case with the SEC. The SEC alleged that Grace \& Company violated generally accepted accounting principles by establishing an all-purpose reserve fund to "smooth" earnings from 1991 to 1995 by hiding profits in good years and using them to disguise slower earnings in latter years. Internal company and audit-firm documents revealed that the Big Five accounting firm that audited Grace \& Company discovered the buildup of earnings in the early 1990s and repeatedly warned company executives that what they were doing was improper. However, even after Grace \& Company began shifting money into earnings in 1993 and 1994, the outside auditors continued to give the company a favorable audit opinion on their financial statements. The accounting firm based their decision on the grounds that it did not view the improprieties as "material" (Davis, 1999).

The argument that the impact of distortions leading to a smoothing of earnings is too small to matter brings into question the motive of why a company would work so hard to bring this about. In today's markets, missing an earnings projection by a few cents can lead to the loss of millions of dollars in the market value of a company's securities. The SEC clearly viewed the distortions by Grace \& Company as material and therefore as a violation of generally accepted accounting principles, as well as a violation of securities laws. As part of the settlement with the SEC, Grace agreed to pay one million dollars to establish a public education program to promote better financial reporting and greater adherence to generally accepted accounting principles (Nielsen, 1999).

\section{Improper Revenue Recognition}

Revenue is generally deemed to be earned and therefore recognized when a product has been shipped or received by the customer, or when a service has been rendered. In most cases this determination is relatively simple. However, for some companies identifying the exact point in time that revenue is earned requires judgment. Once again, ambiguities in the rules open the door for manipulation of earnings by corporate executives determined to do so. Some companies manipulate their earnings by recognizing revenue before a sale is complete, before a product is delivered to the customer, or at a point in time when the customer still has the option to cancel or delay the sale (Levitt, 1998).

In March 2000, MicroStrategy announced that it was changing its revenue recognition policies, and as a result it was restating its 1998 and 1999 reported earnings. The company sold software bundled with multiyear consulting contracts to its customers. However, rather than recognizing the revenue from the sale of the software over the life of the contracts, MicroStrategy recorded it immediately. MicroStrategy decided to change their revenue recognition policy after the SEC began to question the propriety of such tactics among software companies. This change in policy resulted in a change in reported profits of \$12.6 million into a reported loss in excess of $\$ 34$ million. The financial impact was immediate and dramatic. MicroStrategy's stock price collapsed $62 \%$ in a single day, wiping out $\$ 12$ billion in market value ((Sherman and Young, 2001). Ultimately it is the stockholders who are hurt by questionable revenue recognition policies. As a result, the SEC filed a case against MicroStrategy charging them with premature recognition of revenue resulting in incorrect financial statements. That investigation lead to a settlement of fraud charges and \$10 million in fines against several of the company's top executives (Hunt, 2001). 


\section{The Role of Accounting Professionals}

The importance of reliable, efficient, and trustworthy financial markets as a means of providing capital formation can hardly be overstated. Financial markets in other parts of the world have learned the agonizing lesson that if investors are not provided with adequate, informative, and reliable information then the bonds of trust between shareholders and the corporation will be broken. The results are that investors lose confidence in the system, and the financial markets forfeit their role as a stable force in the formation of capital.

Today, the United States capital markets are clearly among the best in the world. This is due in no small part to the confidence that investors have in the system of financial reporting that exist in the U.S. The rules and regulations that have evolved over time have been designed to provide for timely, reliable, comparable, and transparent financial statements. Accounting standards exists as the result of efforts to "standardize", and thus make comparable, the financial reporting of companies. However, recognizing that it is not possible to anticipate every new type of business organization or innovative type of business transaction, the accounting profession developed principles that allow for flexibility in order to adapt to changing business environments. As a result, judgements requiring subjectivity and discretion are often required in the application of generally accepted accounting principles (GAAP). This flexibility in the reporting standards creates an opportunity for individuals so inclined to manipulate the reported earnings of a company. For that reason, it is of the utmost importance that members of the accounting profession maintain the highest standards of objectivity and integrity in the performance of their duties.

The accounting profession in the United States has always had a tradition and reputation for conducting itself in a manner consistent with the highest of ethical standards. However, in recent years questions have arisen concerning the role that accountants play in the inappropriate "management" of corporate earnings. While the presentation of a company's financial statements is the responsibility of top management, the actual preparation of the financial statements is the responsibility of members of the accounting profession. Since 1998 there has been a 28\% increase in the number of accounting-related cases brought by the SEC. In the year 2000 alone, SEC regulators issued 100 financial-fraud actions against U.S. companies (Schroeder, 2001). In each case of financial fraud or reporting failure, the SEC wants to know where were the accountants and what role did they play? All too often in these cases, company accountants or outside auditors either turned a blind eye to the problem or were directly involved in the scheme. In fact, in the year 2000, investigations into financial fraud or reporting failures resulted in the SEC barring 26 corporate CPAs and 11 outside audit professionals from doing work for public companies that fall under the jurisdiction of the SEC (Hunt, 2001)

Of increasing concern to the SEC are the potential conflicts of interest that may arise when accounting firms provide both audit and non-audit services to the same company (Weil, 2001). The SEC cited a recent landmark fraud settlement with the Big Five accounting firm of Arthur Andersen in which it agreed to pay a $\$ 7$ million fine to settle charges that it filed false and misleading audit reports of its client Waste Management. Waste Management admitted that it had overstated its pretax earnings by more than $\$ 1$ billion from 1992 to 1996. The SEC has expressed concern that Arthur Andersen ignored blatant violations of accounting principles due in part to the conflicts of interest caused by the fact that Waste Management was a major client and source of revenue from consulting and non-audit services.

Accountants often face a variety of pressures in their jobs. As discussed earlier, in order to enhance stock values corporate management would generally prefer to report a smooth upward trend in earnings rather than report a widely fluctuating earnings pattern. Nevertheless, accountants should always resist pressure to deliberately smooth or "manage" earnings. They should always refuse to engage in unethical reporting practices such as shifting revenues and expenses between periods, inappropriately capitalizing costs that should be expensed, or misclassifying product and period costs.

Sometimes the correct ethical choices are obvious and clear-cut. But many times the correct ethical thing to do is much more ambiguous, and often the pressure to select the less ethical but more expedient course of action may be enormous. Professional accounting organizations such as the American Institute of CPAs (AICPA) and the 
Institute of Management Accountants (IMA) have established standards of ethical conduct for their members. The established codes of conduct provide standards that co-workers, customers, clients, shareholders, and the general public can expect of members of the accounting profession. In addition, the codes of conduct provide accountants with an acknowledged set of standards that they can draw upon when faced with an ethical dilemma. For example, when confronted by others to engage in an unethical or questionable act, the accounting professional can point to the professional code of ethics as the guiding reference to his actions in those matters. Accounting professionals have an obligation to shareholders, the general public, their profession, the organizations they work for, as well as to themselves to at all times to uphold the highest standards of ethical behavior.

\section{The Role of the Securities and Exchange Commission}

The principal responsibility of the Securities and Exchange Commission (SEC) is to protect investors and to maintain the integrity of the financial markets. The Federal Securities Act of 1933 provided the SEC with the authority to regulate the initial public offerings of a company's securities in order to protect investors from fraud. The Securities Act of 1934 provided the SEC with authority to regulate subsequent trading of securities. In addition, it provided the SEC with the authority to prescribe accounting principles and reporting practices of publicly traded companies. Both acts were passed by Congress in order to help prevent accounting and financial reporting abuses.

Violation of federal securities laws are subject to investigation by the SEC Division of Enforcement. The number of companies under investigation for possible accounting fraud has increased significantly in recent years to nearly 260 (Schroeder, 2001). This is due in large part to what the SEC refers to as an increase in the number of instances of "abusive earnings management" by publicly traded companies. As discussed above, earnings management can be achieved by improper accounting for restructuring costs, improper use of miscellaneous reserves, improper application of the materiality concept, and premature recognition of revenue. Each of these methods can be used to "manage" the timing of revenue and expense recognition, thus enabling companies to meet their projected earnings estimates. In response to the use of these abusive practices by an increasingly large number of companies, the SEC has proposed new regulations to deal with the problem (Stanko, 2001). The proposed "Supplemental Financial Information" legislation is designed to improve clarity of financial reporting by requiring greater disclosure of certain procedures and the underlying accounting assumptions that are made by management in order to justify these procedures.

The SEC also has statutory authority to impose penalties on companies that are in noncompliance with SEC regulations. The SEC's Division of Enforcement has increased its investigation of cases involving financial fraud, especially in the area of inappropriate earnings management. It has created a special Financial Fraud Task Force that is focusing on companies whose financial statements reflect an inappropriate managing of earnings or other apparent violations of generally accepted accounting principles (GAAP). These expanded investigations now include audit work performed by outside accounting firms. The SEC has made clear that it has stepped up its scrutiny of outside auditing firms for failing to prevent and disclose such manipulation by their clients. The SEC has demonstrated its determination to aggressively use all legal remedies, such as substantial fines and the barring of professionals from doing accounting work for publicly traded companies, in order to insure compliance with SEC regulations.

\section{Conclusion}

In recent years, the SEC has expressed a growing concern over the quality of the financial statements of publicly traded companies. When actual results from operations fail to produce the desired income, a significant and increasing number of companies have demonstrated their willingness to manipulate earnings in order to achieve short-term investor expectations. To often, the result is that investors end up losing hundreds of millions of dollars in stock valuations. For example, the 2000 restatement of earnings by MicroStrategy Inc. resulted in a three-day decline in shareholder value of $\$ 11.9$ billion (Weil, 2001).

In large measure, the success of our globalized economy is dependent upon the reliability of the U.S. financial markets. Financial markets exits through the faith of investors. The United States financial markets currently 
benefit from the confidence of investors around the globe. But how much accounting manipulation and misleading financial disclosures will it take to undermine the faith that people have in our markets? Members of the accounting profession must never lose sight of their responsibility to the investing public. Nothing less than the viability of our capital markets is at stake.

\section{References}

1. Beneish, Messod D. 1999. The Detection of Earnings Manipulation. Financial Analysts Journal (September-October): vol. 55, no. 5, 24(13).

2. Davis, Ann. 1999. SEC and W.R. Grace Are Near Accord Over Alleged Earnings Manipulation. Wall Street Journal (June 25): B5.

3. Hunt, Isaac C. Jr. 2001. Financial Reporting Challenges. The CPA Letter (July-August): vol. 81, no. 6, 6(2).

4. Kircheimer, Barbara. 2001. It Still Smarts. Modern Healthcare (June 25): vol. 31, no. 26, 14(2).

5. $\quad$ Levitt, Arthur Jr. 1998. The "Numbers Game." The CPA Journal (December): vol. 68, no. 12, 14(5).

6. Nielsen, Karol. 1999. Grace Settles With SEC On Earnings Manipulation. Chemical Week (July 7-July 14): vol. 161 , no. $26,16$.

7. Schroeder, Michael. 2001. SEC Fines Arthur Andersen in Fraud Case - Big 5 Firm to Pay $\$ 7$ Million After Inquiry of Audits For Waste Management. Wall Street Journal (June 20): A3.

8. $\quad$ Schroeder, Michael. 2001. SEC List of Accounting-Fraud Probes Grows. Wall Street Journal (July 6): C1.

9. Sherman, H. David, and S. David Young. 2001. Tread Lightly Through These Accounting Minefields. Harvard Business Review (July-August): vol. 79, no. 7, 129(7).

10. Stanko, Brian B. 2001. Improving Financial Reporting and Disclosure. Business and Economic Review (July-September): vol. 47, no. 4, 21(5).

11. Weil, Jonathan. 2001. Deals \& Deal Makers: Restatements of Earnings Have Multiplied. Wall Street Journal (June 7): C15.

12. Weil, Jonathan. 2001. SEC Chief Calls Andersen Case "Smoking Gun." Wall Street Journal (June 26): C18. 